\title{
Two Requests on Good Friday in the Preoperative Assessment Clinic
}

\author{
Doug Hester ${ }^{1}$
}

Published online: 13 June 2015

(C) Springer Science+Business Media New York 2015

Hunched over the two canes, her face wincing, her first request was that I swear in convincing assurance that she would emerge pain-free from a three stage revision of her spine.

I offer hopes, but no promises for constant pains.

Her fingers blanch, wrapping around the canes.

The first day she'll be prone, the second supine, lastly, prone again as they excise debris and place new titanium for each worn part.

So we sit here, on Good Friday, reviewing her chart.

Her second request is to rest in a coma until the end, three days entombed in propofol, to descend before she rises. Denied again, she leaves me, hobbling away with her canes, pains, and sorrow. I sigh, and stack the chart atop the heap.

If only we could stay in the solace of our sleep, hiding from today more than tomorrow.

But dawn comes for us all soon enough.

What will we see when we wake and take breath, whether from sleep, from drugs, or from death?

Doug Hester

doug.hester@vanderbilt.edu 